\title{
Kinetics and Mechanism of Aquachlororuthenium (III) Catalyzed Oxidation of Tartaric Acid by Acid Bromate
}

\author{
Ajaya Kumar Singh ${ }^{*, 1}$, Ashok Kumar Singh ${ }^{2}$, Vineeta Singh ${ }^{2, \S}$, Ashish $^{2, \pi}$, Surya Prakash Singh ${ }^{2, \dot{\phi}}$ and \\ B. Singh ${ }^{2}$ \\ ${ }^{I}$ Department of Chemistry, Government V. Y. T. PG. Autonomous College, Durg (Chhattisgarh) 490023, India \\ ${ }^{2}$ Department of Chemistry, University of Allahabad, Allahabad, India
}

\begin{abstract}
The kinetics of the oxidation of Ru (III) catalyzed oxidation of tartaric acid by potassium bromate in aqueous perchloric acid medium at constant ionic strength was investigated in the temperature range $303-318 \mathrm{~K}$. The reactions exhibit first order kinetics at low concentration of bromate, tending to zero order at high concentration. Zero order kinetics with respect to [tartaric acid] and first order kinetics in [Ru (III)] were observed in the oxidation of tartaric acid. A positive effect on the rate of reaction has been found on the successive addition of $\left[\mathrm{H}^{+}\right]$and $\left[\mathrm{Cl}^{-}\right]$. Variation in mercuric acetate concentration, $[\mathrm{Hg}(\mathrm{OAc}) 2]$ and ionic strength of the medium did not bring any significant change on the rate of reaction. The first order rate constant increases with decrease in the dielectric constant of the medium. The values of rate constants observed at four different temperatures were utilized to calculate the activation parameters. Formic acid and carbon dioxide have been identified as main oxidation products of the reaction. A plausible mechanism from the results of kinetic studies, reaction stoichiometry and product analysis has been proposed.
\end{abstract}

Keywords: Kinetics, oxidation, $\mathrm{Ru}$ (III) chloride, tartaric acid, $\mathrm{HClO} 4$.

\section{INTRODUCTION}

Tartaric acid (TA) is used in the food, cosmetics, and pharmaceutical, textiles, coloring and printing sectors. It plays an important role chemically, lowering the $\mathrm{pH}$ of fermenting "must" to a level where many undesirable spoilage bacteria cannot live and also act as a preservative after fermentation in the mouth. Tartaric acid provides some of the tartness that is currently out of fashion in the wine world. Oxidation of tartaric acid is of importance, as it adds to the body of knowledge of redox chemistry. The oxidation products depend on the type of oxidant and on the reaction medium. Kinetic studies on the oxidation of tartaric acid with different oxidants such as N-bromophthalimide [1-7], N-bromoacetamide [8], silver (II) [9], N-bromosuccinimide [10], $\mathrm{Cr}$ (VI) in aqueous perchloric acid medium [11], alkaline hexacynoferrate (III) [12], alkaline iodate [13] and chloramine - T [14-16] have been reported earlier. Potassium bromate $[\mathrm{Br}(\mathrm{V})]$ is known to be a powerful oxidizing agent with redox potentials of $1.44 \mathrm{~V}$ in acid medium and $0.61 \mathrm{~V}$ in alkaline medium. It has widely been used in the oxidation of many organic compounds [17-21]. The bromate $\left(\mathrm{BrO}_{3}^{-}\right)$ species has been reported as an oxidizing agent in acidic as

*Address correspondence to this author at the Department of Chemistry, Government V. Y. T. PG. Autonomous College, Durg (Chhattisgarh) 490023, India; Tel: +917882223421; E-mail: ajayaksingh_au@yahoo.co.in

${ }^{\S}$ Present Address: Department of Chemistry, DAV PG College Lucknow, India.

"Present Address: Samtel Center for Display Technologies, IIT Kanpur, India.

${ }^{8}$ Present Address: IICT, Hyderabad, India. well as in alkaline medium $[18,19]$. Earlier it was reported that bromide ion, formed by the reduction of $\mathrm{BrO}_{3}{ }^{-}$give rise to molecular bromine which sets parallel oxidation of TA. In order to obviate molecular bromine oxidation and to ensure pure bromate oxidation, mercuric acetate, which is used as bromide ion scavenger [22] was added to the reaction mixture. The kinetics of redox reactions involving homogeneous catalyst such as platinum group metals particularly Osmium (VIII), Iridium (III) and Palladium (II) have extensively been investigated from the mechanistic point of view. The mechanism of reaction depends upon the nature of the oxidant, nature of the substrate and the ways in which transition metal complex ions play their role in order to promote the reactant molecules to the activated state before changing into final products under experimental conditions. Mechanistic aspects of much redox reaction have been well documented by many workers. However, literature survey reveled that, there are sparse efforts from the kinetic and mechanistic points of view on the oxidation of TA by bromate. Sen Gupta et al. [23] studied the oxidative behaviors and relative reactivities of some $\alpha$-hydroxy acids towards bromate ion in hydrochloric acid medium. They have reported it is a first order reaction with respect to bromate ion, $\alpha$-hydroxy acids and hydrogen ion. In the present work, we report kinetics and mechanism of oxidation of tartaric acid by potassium bromate in the presence of $\mathrm{Ru}$ (III) in aqueous homogeneous acidic system at $308 \mathrm{~K}$. Objectives of the present study are : (i) to elucidate a plausible mechanism, (ii) to identify the oxidation products, (iii) to deduce an appropriate rate law, (iv) to ascertain the various reactive species of catalyst and oxidant and (v) to calculate activation parameters. 


\section{EXPERIMENTAL}

\subsection{Material}

Sodium perchlorate, potassium bromate, perchloric acid, tartaric acid, mercuric acetate (E. Merck) were used as supplied without further purification by preparing their solutions in doubly distilled water. A stock solution of $\mathrm{Ru}$ (III) chloride (Johnson Metthey) was prepared by dissolving the sample in hydrochloric acid of known strength. Mercury was added to $\mathrm{Ru}$ (III) solution to reduce any Ru (IV) formed during the preparation of stock solution of $\mathrm{Ru}$ (III) chloride. This solution was kept for 24 hours. The Ruthenium (III) concentration was assayed [21] by EDTA titration. An allowance for the amount of hydrochloric acid present in the catalyst solution was made while preparing the reaction mixtures for kinetic studies. Sodium perchlorate was used to maintain the ionic strength of the medium. All other reagents were of AnalaR grade and doubly distilled water was used throughout the work. The reaction vessels were coated from outside with black paint to avoid any photochemical reaction.

\subsection{Kinetic Procedure}

A thermostated water bath was used to maintain the desired temperature within $\pm 0.1{ }^{\circ} \mathrm{C}$. The calculated amount of the reactants i.e. potassium bromate, perchloric acid, mercuric acetate, sodium perchlorate, $\mathrm{Ru}$ (III) chloride and water, except tartaric acid were taken in a reaction vessel which was kept in a thermostatic water bath. After allowing sufficient time to attain the temperature of the experiment, requisite amount of tartaric acid solution, also thermostated at the same temperature was rapidly pipette out and run into the reaction vessel. The total volume of reaction mixture was $100 \mathrm{ml}$ in each case. $5 \mathrm{ml}$ aliquots of reaction mixture was pipetted out at different intervals of time and quenched with $4 \%$ potassium iodide containing $5 \mathrm{ml}$ of known strength of perchloric acid solution. Measuring the unconsumed amount of potassium bromate iodometrically monitored the progress of reaction. Remaining amount of potassium bromate will liberate an equivalent amount of iodine from potassium iodide solution, which was titrated against a standard solution of sodium thiosulphate using starch as an indicator. The rate of reaction $(-\mathrm{dc} / \mathrm{dt})$ was determined by the slope of the tangent drawn at a fixed $\left[\mathrm{BrO}_{3}{ }^{-}\right]$in each kinetic run. The order of reaction in each reactant was measured with the help of $\log -\log$ plot of $(-\mathrm{dc} / \mathrm{dt})$ versus concentration of the reactants.

\subsection{Stoichiometry and Product Analysis}

The reaction mixture containing the tartaric acid, mercuric acetate, $\mathrm{Ru}$ (III) chloride and perchloric acid with excess of potassium bromate was kept for 72 hours at $35^{\circ} \mathrm{C}$. Determination of unconsumed bromate revealed that for the oxidation of each mole of TA, one mole of bromate was required. Accordingly, the following stoichiometric equation (1) can be formulated:

$$
\int_{\mathrm{CH}(\mathrm{OH}) \mathrm{CHOOH}}^{\mathrm{CH}(\mathrm{OH}) \mathrm{COOH}}+\mathrm{BrO}_{3}^{-} \stackrel{\mathrm{Ru}(\mathrm{III}) / \mathrm{H}^{+}}{[\mathrm{O}]} \mathrm{HCOOH}+3 \mathrm{CO}_{2}+2 \mathrm{H}_{2} \mathrm{O}+\mathrm{Br}^{-}
$$

Formic acid and carbon dioxide were identified as the main oxidation products in the oxidation of tartaric acid. The formic acid was analyzed by NUCON gas chromatography using porapak-Q 101 columns and programmed oven temperature having FID detector. The major product was identified as formic acid by comparison of retention time with the retention time of standard solutions. Formic acid was also confirmed by spot test [24]. $\mathrm{CO}_{2}$ was identified by bubbling $\mathrm{N}_{2}$ gas through the reaction mixture and passing the liberated gas through a U-shaped tube containing a saturated $\mathrm{Ba}(\mathrm{OH})_{2}$ solutions. Bromide ion was estimated by adding $\mathrm{AgNO}_{3}$ solution which in turn resulted the formation of a pale yellow precipitate of silver bromide. On the basis of equivalence and kinetic studies, it was concluded that formic acid and $\mathrm{CO}_{2}$ were the oxidation products in the $\mathrm{Ru}$ (III) chloride catalyzed oxidation of tartaric acid by potassium bromate in acidic medium.

\section{KINETIC RESULTS AND DISCUSSION}

The kinetics of $\mathrm{Ru}$ (III) catalyzed oxidation of TA by potassium bromate was investigated at several initial concentrations of the reactants in perchloric acid medium at $35^{\circ} \mathrm{C}$. The rate (i.e. $-\mathrm{dc} / \mathrm{dt}$ ) of the reaction in each kinetic run was determined by the slope of the tangent drawn at fixed concentration of oxidant, potassium bromate, which is written as $\left[\mathrm{BrO}_{3}{ }^{-}\right]^{*}$. In the variation of oxidant, $\mathrm{BrO}_{3}{ }^{-}$tangent has been drawn at a fixed time. The first order rate constant $\left(\mathrm{k}_{1}\right)$ was calculated as

$\mathrm{k}_{1}=(-\mathrm{dc} / \mathrm{dt}) /\left[\mathrm{BrO}_{3}{ }^{-}\right]^{*}$

The first order dependence of reaction on $\mathrm{BrO}_{3}^{-}$at its lower concentrations tends to zeroth order at its higher concentrations. This is also obvious from the plot of $(-\mathrm{dc} / \mathrm{dt})$ versus $\left[\mathrm{BrO}_{3}^{-}\right]$(Table 1, Fig. 1), indicating first order kinetics at lower concentrations and tending to zero order kinetics at its higher concentrations. The rate of the reaction $(-\mathrm{dc} / \mathrm{dt})$, was calculated at different concentrations of tartaric acid [TA] at constant $\mathrm{pH}$ showing zero order kinetics with respect to $[\mathrm{TA}]$ (Table 1). Since order of reaction with respect to TA is zero, in each kinetic run, the rate of reaction $(-\mathrm{dc} / \mathrm{dt})$, will always be equal to the standard zero order rate constant. The plot of rate constant $\mathrm{k}_{1}$ versus [Ru (III)] was linear passing through the origin, suggesting first- order dependence of the rate of reaction on the [Ru (III)]. At the same time, it also shows that the reaction did not proceed with measurable velocity in the absence of [Ru (III)] (Table 1, Fig. 2). Further, the second order rate constant $k_{2}=k_{1} /[R u$ (III)] was constant confirming the first - order dependence on [Ru (III)]. Kinetics of catalyzed oxidation of TA indicates that on increasing $\left[\mathrm{HClO}_{4}\right]$, the value of $(-\mathrm{dc} / \mathrm{dt})$ increases without following any relationship; which is also evident from the plot of $(-\mathrm{dc} / \mathrm{dt})$ versus $\left[\mathrm{HClO}_{4}\right]$ (Table 2, Fig. 3). This shows positive effect of $\left[\mathrm{H}^{+}\right]$on the rate of oxidation of TA. On increasing the $\left[\mathrm{Cl}^{-}\right]$, the value of $(-\mathrm{dc} / \mathrm{dt})$ increases. When $(-\mathrm{dc} / \mathrm{dt})$ values were plotted against $\left[\mathrm{Cl}^{-}\right]$, a curve (Table 2, Fig. 4) showing positive effect on the rate of reaction was observed. Variation of the ionic strength of the medium (I) by adding sodium perchlorate $\left(0.2-1.8 \mathrm{~mol} \mathrm{dm}^{-3}\right)$ had no effect on the rate of oxidation of TA catalyzed by $\mathrm{Ru}$ (III) using potassium bromate as oxidant in acidic medium (Table 2). Variation of mercuric acetate did not bring any 
Table 1. Effect of Variation of $\left[\mathrm{KBrO}_{3}\right]$, $[\mathrm{TA}]$ and $[\mathrm{Ru}(\mathrm{III})]$ on the Rate of Reaction at $35^{\circ} \mathrm{C}$. Solution $\mathrm{Conditions}^{-}\left[\mathrm{HClO}_{4}\right]=$ $8.00 \times 10^{-1} \mathrm{~mol} \mathrm{dm}^{-3},\left[\mathrm{Hg}(\mathrm{OAc})_{2}\right]=4.00 \times 10^{-3} \mathrm{~mol} \mathrm{dm}^{-3},[\mathrm{KCl}]=10^{-3} \mathrm{~mol} \mathrm{dm}^{-3}$

\begin{tabular}{|c|c|c|c|c|}
\hline$\left[\mathrm{KBrO}_{3}\right] \times 10^{4}\left(\mathrm{~mol} \mathrm{dm}^{-3}\right)$ & [TA] $\times 10\left(\mathrm{~mol} \mathrm{dm}^{-3}\right)$ & {$[\mathrm{Ru}(\mathrm{III})] \times 1^{5}\left(\mathrm{~mol} \mathrm{dm}^{-3}\right)$} & $(-\mathrm{dc} / \mathrm{dt}) \times 10^{7}\left(\mathrm{~mol} \mathrm{dm}^{-3} \mathrm{~s}^{-1}\right)$ & $k_{1} \times 10^{4}\left(s^{-1}\right)$ \\
\hline 1.20 & 1.00 & 9.15 & 0.19 & 1.77 \\
\hline 2.00 & 1.00 & 9.15 & 0.32 & 1.77 \\
\hline 4.00 & 1.00 & 9.15 & 0.65 & 1.80 \\
\hline 8.00 & 1.00 & 9.15 & 1.29 & 1.79 \\
\hline 10.00 & 1.00 & 9.15 & 1.60 & 1.77 \\
\hline 12.00 & 1.00 & 9.15 & 1.67 & 1.51 \\
\hline 16.00 & 1.00 & 9.15 & 1.82 & 1.21 \\
\hline 20.00 & 1.00 & 9.15 & 2.08 & 1.09 \\
\hline 10.00 & 0.50 & 9.15 & 1.48 & 1.64 \\
\hline 10.00 & 1.00 & 9.15 & 1.50 & 1.67 \\
\hline 10.00 & 1.50 & 9.15 & 1.52 & 1.68 \\
\hline 10.00 & 2.00 & 9.15 & 1.56 & 1.72 \\
\hline 10.00 & 3.00 & 9.15 & 1.54 & 1.71 \\
\hline 10.00 & 4.00 & 9.15 & 1.56 & 1.72 \\
\hline 10.00 & 1.00 & 1.53 & 0.25 & 0.28 \\
\hline 10.00 & 1.00 & 3.06 & 0.51 & 0.57 \\
\hline 10.00 & 1.00 & 6.10 & 1.01 & 1.12 \\
\hline 10.00 & 1.00 & 9.15 & 1.59 & 1.77 \\
\hline 10.00 & 1.00 & 12.24 & 2.00 & 2.22 \\
\hline 10.00 & 1.00 & 15.26 & 2.50 & 2.78 \\
\hline
\end{tabular}

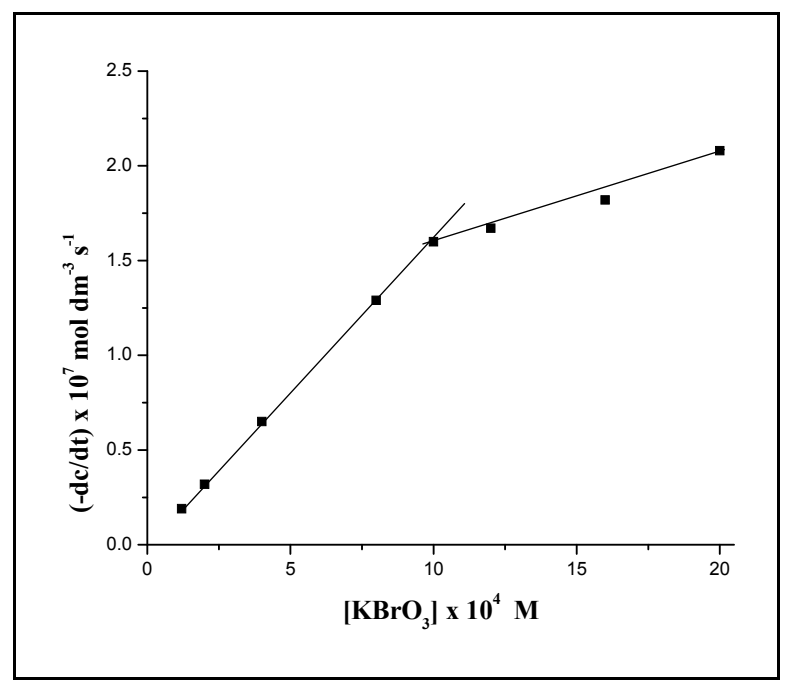

Fig. (1). Plot between rate of reaction $(-\mathrm{dc} / \mathrm{dt})$ and $\left[\mathrm{KBrO}_{3}\right]$ at $35^{\circ} \mathrm{C}$, $[\mathrm{Ru}(\mathrm{III})]=9.15 \times 10^{-5} \mathrm{~mol} \mathrm{dm}^{-3}$, [TA $]=1.0 \times 10^{-1} \mathrm{~mol} \mathrm{dm}{ }^{-3}$, $[\mathrm{HClO} 4]=0.8 \times 10^{-1} \mathrm{~mol} \mathrm{dm}^{-3},\left[\mathrm{Hg}(\mathrm{OAc})_{2}\right]=4.00 \times 10^{-3} \mathrm{~mol} \mathrm{dm}^{-3}$, $[\mathrm{KCl}]=10^{-3} \mathrm{~mol} \mathrm{dm}^{-3}$.

significant change in $\mathrm{k}_{1}$ values under the constant experimental conditions (Table 2). The rate of reaction increased with decrease in dielectric constant of the medium (by increasing the \% of acetic acid by volume) (Table 3 ). Control experiments showed that acetic acid was not oxidized by potassium bromate under the experimental conditions. The reaction was studied at different temperatures (303-318 K) and from the linear Arrhenius plots of $\log \mathrm{k}_{1}$ versus $1 / \mathrm{T}$, the activation energy Ea was calculated. With the help of the rate constant $k_{r}$, values of the other activation parameters such as enthalpy of activation $\left(\Delta \mathrm{H}^{\#}\right)$, entropy of activation $\left(\Delta \mathrm{S}^{\#}\right)$, Gibbs free energy of activation $\left(\Delta G^{\#}\right)$ and Arrhenius factor, i.e. A, were calculated and are given in Table 4.

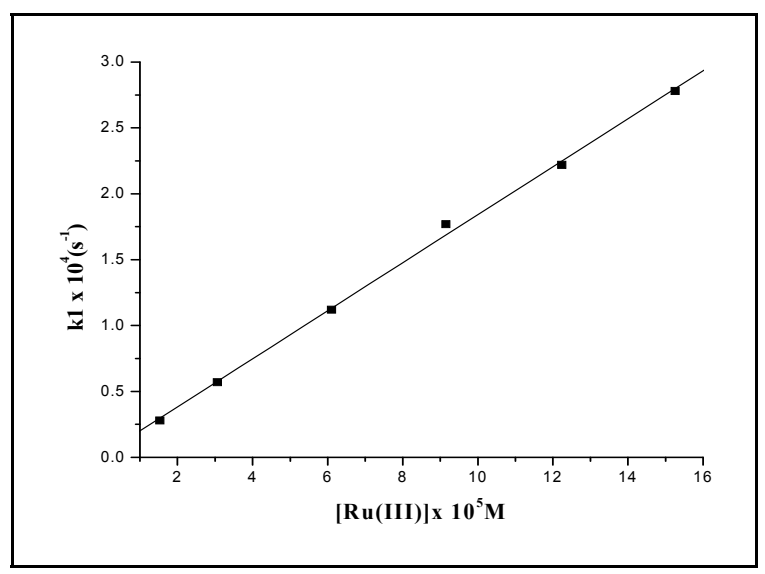

Fig. (2). Plot between first order rates constant $\left(\mathrm{k}_{1}\right)$ and $[\mathrm{Ru}(\mathrm{III})]$ at $35^{\circ} \mathrm{C},\left[\mathrm{KBrO}_{3}\right]=10 \times 10^{-4} \mathrm{~mol} \mathrm{dm}^{-3},[\mathrm{TA}]=1.0 \times 10^{-1} \mathrm{~mol} \mathrm{dm}{ }^{-3}$, $[\mathrm{HClO} 4]=0.8 \times 10^{-1} \mathrm{~mol} \mathrm{dm}^{-3},\left[\mathrm{Hg}(\mathrm{OAc})_{2}\right]=4.00 \times 10_{-3} \mathrm{~mol} \mathrm{dm}_{-3}$, $[\mathrm{KCl}]=10^{-3} \mathrm{~mol} \mathrm{dm}^{-3}$. 
Table 2. Effect of Variation of $\left[\mathrm{HClO}_{4}\right],[\mathrm{KCl}],[\mathrm{I}]$ and $\left[\mathrm{Hg}(\mathrm{OAc})_{2}\right]$ on the Rate of Reaction and Rate Constant at $35^{\circ} \mathrm{C}$. Solution Conditions: $\left[\mathrm{KBrO}_{3}\right]=10.0 \times 10^{-4} \mathrm{~mol} \mathrm{dm}^{-3}$, $[\mathrm{TA}]=2.00 \times 10^{-1} \mathrm{~mol} \mathrm{dm}^{-3}$, $[\mathrm{Ru}(\mathrm{III})]=9.15 \times 10^{-5} \mathrm{~mol} \mathrm{dm}^{-3}$

\begin{tabular}{|c|c|c|c|c|c|}
\hline$\left[\mathrm{H}^{+}\right] \times 10 \mathrm{~mol} \mathrm{dm}^{-3}$ & {$[\mathrm{KCl}] \times 10^{2} \mathrm{~mol} \mathrm{dm}^{-3}$} & [I] $\mathrm{mol} \mathrm{dm}^{-3}$ & $\left.[\mathrm{HgOAc})_{2}\right] \times 10^{3} \mathrm{~mol} \mathrm{dm}^{-3}$ & $(-\mathrm{dc} / \mathrm{dt}) \times 10^{7} \mathrm{~mol} \mathrm{dm}^{-3}$ & $k_{1} \times 10^{4}\left(s^{-1}\right)$ \\
\hline 1.20 & 0.10 & & 1.60 & 0.52 & 0.09 \\
\hline 2.40 & 0.10 & & 1.60 & 0.58 & 1.10 \\
\hline 4.80 & 0.10 & & 1.60 & 1.25 & 1.39 \\
\hline 8.00 & 0.10 & & 1.60 & 1.78 & 1.98 \\
\hline 9.60 & 0.10 & & 1.60 & 1.87 & 2.08 \\
\hline 12.00 & 0.10 & & 1.60 & 2.08 & 2.31 \\
\hline 8.00 & 0.00 & & 1.60 & 1.60 & 1.78 \\
\hline 8.00 & 0.40 & & 1.60 & 1.78 & 1.98 \\
\hline 8.00 & 0.60 & & 1.60 & 2.26 & 2.51 \\
\hline 8.00 & 0.80 & & 1.60 & 2.58 & 2.87 \\
\hline 8.00 & 1.00 & & 1.60 & 3.03 & 3.37 \\
\hline 8.00 & 2.00 & & 1.60 & 4.50 & 5.10 \\
\hline 8.00 & 0.10 & & 1.20 & 1.65 & 1.83 \\
\hline 8.00 & 0.10 & & 2.40 & 1.62 & 1.80 \\
\hline 8.00 & 0.10 & & 4.80 & 1.67 & 1.85 \\
\hline 8.00 & 0.10 & & 7.20 & 1.59 & 1.77 \\
\hline 8.00 & 0.10 & & 9.60 & 1.55 & 1.72 \\
\hline 8.00 & 0.10 & & 12.00 & 1.61 & 1.79 \\
\hline 2.00 & - & 0.20 & 1.60 & 1.61 & 1.79 \\
\hline 2.00 & - & 0.40 & 1.60 & 1.60 & 1.78 \\
\hline 2.00 & - & 0.60 & 1.60 & 1.60 & 1.78 \\
\hline 2.00 & - & 1.00 & 1.60 & 1.59 & 1.77 \\
\hline 2.00 & - & 1.40 & 1.60 & 1.62 & 1.80 \\
\hline 2.00 & - & 1.60 & 1.60 & 1.60 & 1.78 \\
\hline 2.00 & - & 2.00 & 1.60 & 1.60 & 1.78 \\
\hline 1.20 & 0.10 & & 1.60 & 0.52 & 0.09 \\
\hline
\end{tabular}

Table 3. Effect of Variation of \% Acetic Acid on the Rate of Reaction and Rate Constant at $35^{\circ} \mathrm{C}$. Solution conditions: $\left[\mathrm{KBrO}_{3}\right]=10.0 \times 10^{-4} \mathrm{~mol} \mathrm{dm}^{-3}$, $[\mathrm{TA}]=$ $2.00 \times 10^{-1} \mathrm{~mol} \mathrm{dm}^{-3}$, $[\mathrm{Ru}(\mathrm{III})]=9.15 \times 10^{-5} \mathrm{~mol} \mathrm{dm}^{-3}$, $\left[\mathrm{HClO}_{4}\right]=8.00 \times 10^{-1} \mathrm{~mol} \mathrm{dm}^{-3},\left[\mathrm{Hg}(\mathrm{OAc})_{2}\right]=4.00 \times 10^{-}$ ${ }^{3} \mathrm{~mol} \mathrm{dm}^{-3}$, $[\mathrm{KCl}]=10^{-3} \mathrm{~mol} \mathrm{dm}^{-3}$

\begin{tabular}{|c|c|c|}
\hline$\%$ Acetic Acid & $(-\mathrm{dc} / \mathrm{dt}) \times 10^{7} \mathrm{M} \mathrm{sec} \mathrm{se}^{-1}$ & $\mathrm{k} \times 10^{4} \mathrm{sec}^{-1}$ \\
\hline 0 & 1.53 & 1.62 \\
\hline 5 & 1.73 & 1.82 \\
\hline 10 & 3.60 & 3.71 \\
\hline 20 & 6.32 & 6.60 \\
\hline 30 & 12.40 & 13.52 \\
\hline 40 & 40.95 & 41.32 \\
\hline
\end{tabular}

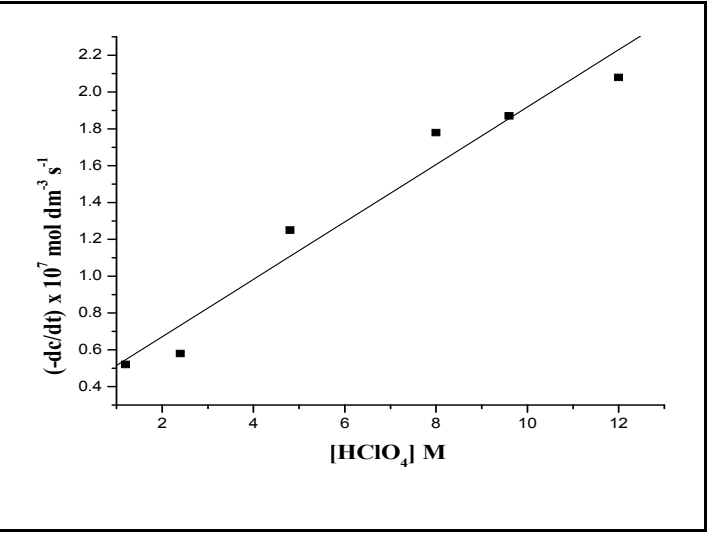

Fig. (3). Plot between rate of reaction and $\left[\mathrm{HClO}_{4}\right]$ at $35^{\circ} \mathrm{C}$, $\left[\mathrm{KBrO}_{3}\right]=10 \times 10_{-4} \mathrm{~mol} \mathrm{dm}_{-3},[\mathrm{TA}]=2.0 \times 10^{-1} \mathrm{~mol} \mathrm{dm}^{-3},[\mathrm{Ru}(\mathrm{III})]$ $=9.15 \times 10^{-5} \mathrm{~mol} \mathrm{dm}^{-3},\left[\mathrm{Hg}(\mathrm{OAc})_{2}\right]=1.60 \times 10^{-3} \mathrm{~mol} \mathrm{dm}^{-3},[\mathrm{KCl}]=$ $10^{-3} \mathrm{~mol} \mathrm{dm}^{-3}$. 


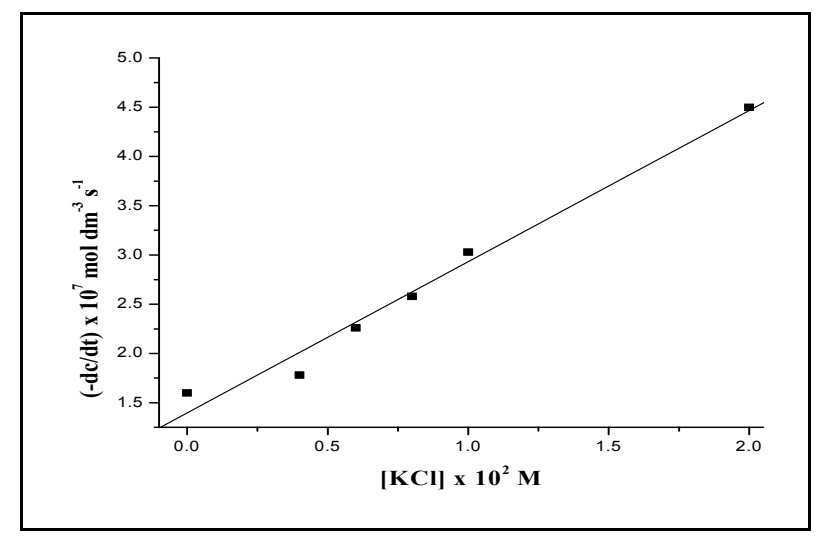

Fig. (4). Plot between rate of reaction and $\left[\mathrm{Cl}^{-}\right]$at $35^{\circ} \mathrm{C},\left[\mathrm{KBrO}_{3}\right]=$ $10 \times 10^{-4} \mathrm{~mol} \mathrm{dm}^{-3},[\mathrm{TA}]=2.0 \times 10^{-1} \mathrm{~mol} \mathrm{dm}^{-3},[\mathrm{Ru}(\mathrm{III})]=9.15 \mathrm{x}$ $10^{-5} \mathrm{~mol} \mathrm{dm}^{-3},\left[\mathrm{Hg}(\mathrm{OAc})_{2}\right]=1.60 \times 10^{-3} \mathrm{~mol} \mathrm{dm}^{-3},\left[\mathrm{H}^{+}\right]=0.8 \times 10^{-1}$ mol dm ${ }^{-3}$.

Table 4. Effect of Temperature on the Rate Constant and Values of Activation Parameters. Solution Conditions: $\left[\mathrm{KBrO}_{3}\right]=10 \times 10^{-4} \mathrm{~mol} \mathrm{dm}^{-3}$; $[\mathrm{TA}]=2 \mathrm{x}$ $10^{-1} \mathrm{~mol} \mathrm{dm}^{-3}$, $[\mathrm{Ru}(\mathrm{III})]=9.15 \times 10^{-5} \mathrm{~mol} \mathrm{dm}^{-3} ;\left[\mathrm{HClO}_{4}\right]$ $=8.00 \times 10^{-1} \mathrm{~mol} \mathrm{dm}^{-3},\left[\mathrm{Hg}(\mathrm{OAc})_{2}\right]=1.60 \times 10^{-3} \mathrm{~mol}$ $\mathbf{d m}^{-3}$

\begin{tabular}{|c|c|}
\hline Parameters & Values \\
\hline \hline $\mathrm{Ea}\left(\mathrm{kJ} \mathrm{mol}^{-1}\right)$ & 62.87 \\
\hline $\mathrm{k}_{\mathrm{r}}\left(\mathrm{mol}^{-2} \mathrm{lit}^{2} \mathrm{sec}^{-1}\right)$ & 1.91 \\
\hline$\Delta \mathrm{H}^{\#}\left(\mathrm{~kJ} \mathrm{~mol}^{-1}\right)$ & 60.27 \\
\hline$\Delta \mathrm{S}^{\#}\left(\mathrm{JK}^{-1} \mathrm{~mol}^{-1}\right)$ & -2.94 \\
\hline$\Delta \mathrm{G}^{\#} \mathrm{~kJ} \mathrm{~mol}^{-1}$ & 74.13 \\
\hline $\mathrm{A}\left(\mathrm{mol}^{-2} l \mathrm{li}^{2} \mathrm{sec}^{-1}\right)$ & $8.00 \times 10^{10}$ \\
\hline $\mathrm{Temp}(\mathrm{K})$ & $\mathrm{k} \mathrm{x} \mathrm{10-4}\left(\mathrm{s}^{-1}\right)$ \\
\hline
\end{tabular}

On the basis of observed first to zero order kinetics with respect to bromate, Zero order kinetics in TA, first order kinetics with respect to $\mathrm{Ru}(\mathrm{III})$, and positive effect of $\left[\mathrm{H}^{+}\right]$ and $\left[\mathrm{Cl}^{-}\right]$on the rate of reaction, the following experimental rate law can be expressed as: CHECK THE SENTENCE

$$
-\frac{\mathrm{d}\left[\mathrm{BrO}_{3}^{-}\right]}{\mathrm{dt}}=\frac{\mathrm{k}\left[\mathrm{BrO}_{3}^{-}\right][\mathrm{Ru}(\mathrm{III})]\left[\mathrm{H}^{+}\right]\left[\mathrm{Cl}^{-}\right]}{\mathrm{x}+\mathrm{y}\left[\mathrm{BrO}_{3}^{-}\right]+\mathrm{z}\left[\mathrm{H}^{+}\right]+\mathrm{a}\left[\mathrm{Cl}^{-}\right]}
$$

\subsection{Test for Free Radical}

The addition of the reaction mixtures to aqueous acryl amide monomer solutions, in the dark, did not initiate polymerization, indicating the absence of formation of free radical species in the reaction sequence. The control experiments were also performed under the same reaction conditions.

\subsection{Discussion and Mechanism}

The following form of rate law, valid for the conditions under which temperature dependence has been measured, was used to calculate the activation parameters in the $\mathrm{Ru}$
(III) chloride catalyzed oxidation of TA by potassium bromate in acidic medium.

$$
-\frac{\mathrm{d}\left[\mathrm{BrO}_{3}^{-}\right]}{\mathrm{dt}}=\mathrm{k}_{\mathrm{r}}\left[\mathrm{BrO}_{3}^{-}\right]^{\mathrm{a}}[\mathrm{Ru}(\mathrm{III})]^{\mathrm{b}}\left[\mathrm{H}^{+}\right]^{\mathrm{c}}\left[\mathrm{Cl}^{-}\right]^{\mathrm{d}}
$$

Electronic spectral studies of Cady and Connick [25], and Connick and Fine [26] reveal that species such as $\left[\mathrm{RuCl}_{5}\left(\mathrm{H}_{2} \mathrm{O}\right)\right]^{2-}, \quad\left[\mathrm{RuCl}_{4}\left(\mathrm{H}_{2} \mathrm{O}\right)_{2}\right]^{-}, \quad\left[\mathrm{RuCl}_{3}\left(\mathrm{H}_{2} \mathrm{O}\right)_{3}\right], \quad\left[\mathrm{RuCl}_{2}\right.$ $\left.\left.\mathrm{H}_{2} \mathrm{O}\right)_{4}\right]^{+}$and $\left[\mathrm{RuCl}\left(\mathrm{H}_{2} \mathrm{O}\right)_{5}\right]^{2+}$ do not exist in an aqueous solution of $\mathrm{RuCl}_{3}$. A study on the oxidation states of ruthenium has shown that $\mathrm{Ru}$ (III) exists $[27,28]$ in the acid medium as:

$$
\begin{aligned}
& \mathrm{RuCl}_{3} \cdot \mathrm{xH}_{2} \mathrm{O}+3 \mathrm{HCl} \longrightarrow\left[\mathrm{RuCl}_{6}\right]^{3-}+\mathrm{x} \mathrm{H}_{2} \mathrm{O}+3 \mathrm{H}^{+} \\
& {\left[\mathrm{RuCl}_{6}\right]^{3-}+\mathrm{H}_{2} \mathrm{O} \rightleftharpoons\left[\mathrm{RuCl}_{5}\left(\mathrm{H}_{2} \mathrm{O}\right)\right]^{2-}+\mathrm{Cl}^{-}}
\end{aligned}
$$

Singh et al. [29, 30] employed the above equilibrium in $\mathrm{Ru}$ (III) catalyzed oxidation of D-galactose and D-ribose by $\mathrm{N}$-bromoacetamide, butanone and pentanone-3 by Ce (IV), and erythritol and dulcitol by N-bromoacetamide in acid medium. Taqui Khan et al. [31] reported that at the instant of preparation, $\mathrm{Ru}$ (III) exists in the $\mathrm{pH}$ range $0.4-2.0$ as four major species $\left[\mathrm{RuCl}_{4}\left(\mathrm{H}_{2} \mathrm{O}\right)_{2}\right]^{-},\left[\mathrm{RuCl}_{3}\left(\mathrm{H}_{2} \mathrm{O}\right)_{3}\right],\left[\mathrm{RuCl}_{2}\left(\mathrm{H}_{2} \mathrm{O}\right)_{4}\right]^{+}$ and $\left[\mathrm{RuCl}\left(\mathrm{H}_{2} \mathrm{O}\right)_{5}\right]^{2+}$. Out of these four species, $\left[\mathrm{RuCl}_{2}\left(\mathrm{H}_{2} \mathrm{O}\right)_{4}\right]^{+}$is stabilized in its hydrolyzed form $\left[\mathrm{RuCl}_{2}\left(\mathrm{H}_{2} \mathrm{O}\right)_{3} \mathrm{OH}\right]$ according to the following equilibrium

$\left[\mathrm{RuCl}_{2}\left(\mathrm{H}_{2} \mathrm{O}\right)_{4}\right]^{+}+\mathrm{H}_{2} \mathrm{O} \rightleftharpoons\left[\mathrm{RuCl}_{2}\left(\mathrm{H}_{2} \mathrm{O}\right)_{3} \mathrm{OH}\right]+\mathrm{H}_{3} \mathrm{O}^{+}$

The experiments were performed with $\mathrm{Ru}$ (III) chloride dissolved in $0.01 \mathrm{M} \mathrm{HCl}$ solution and throughout the study, the $\mathrm{pH}$ of the solution was maintained in between 0.4 and 2.0. However, in the present study, addition of $\mathrm{Cl}^{-}$ion in the form of $\mathrm{KCl}$ at fixed $\left[\mathrm{H}^{+}\right]$had positive effect on the rate of reaction. Hence $\left[\mathrm{RuCl}_{2}\left(\mathrm{H}_{2} \mathrm{O}\right)_{3} \mathrm{OH}\right]$ can safely be assumed to be the reactive species of ruthenium (III) chloride in the present investigation. The existence of the sole species of $\mathrm{Ru}$ (III) chloride in acidic medium as $\left[\mathrm{RuCl}_{2}\left(\mathrm{H}_{2} \mathrm{O}\right)_{3} \mathrm{OH}\right]$ is also confirmed by the spectrum of $\mathrm{Ru}$ (III) chloride solution( 4.38 $\left.\mathrm{x} 10^{-4} \mathrm{M}\right)$ in the presence of $\mathrm{HCl}\left(1 \times 10^{-2} \mathrm{M}\right)$ where a single peak at $\lambda_{\max }=210 \mathrm{~nm}$.

In the oxidation of TA, mercuric acetate was used as bromide ion scavenger $[17,18]$ to eliminate the $\mathrm{Br}^{-}$ion and this could have produced $\mathrm{Br}_{2}$ in the following reaction

$\mathrm{BrO}_{3}^{-}+5 \mathrm{Br}^{-}+6 \mathrm{H}^{+} \rightleftharpoons 3 \mathrm{Br}_{2}+3 \mathrm{H}_{2} \mathrm{O}$

The bromine, thus produced might have set another parallel oxidation and might have created complication in bromate oxidation. Mercuric (II) acetate thus obviates molecular bromine oxidation and ensures that the oxidation proceeds purely through $\mathrm{KBrO}_{3}$. It has been reported earlier that $\mathrm{Hg}$ (II) can also act as an oxidant as well as catalyst [32] in the reaction. To ascertain the real role of $\mathrm{Hg}$ (II) in addition to its function as bromide ion scavenger, several experiments were performed with mercuric acetate in the absence of $\mathrm{KBrO}_{3}$ under identical experimental conditions. It has been observed that the reaction does not proceed. This rule out the possibility of $\mathrm{Hg}$ (II) acting as an oxidant under present conditions of experiments. Further, kinetic observations showed that the rate of reaction was almost constant with increasing concentration of mercuric (II) acetate with potassium bromate as an oxidant. These rules out the catalytic role of $\mathrm{Hg}$ (II) acetate. Thus in view of such 
kinetic experimental observations, mercuric (II) acetate acts as bromide ion scavenger only in the form of either unionized $\mathrm{HgBr}_{2}$ or as complex $\left[\mathrm{HgBr}_{4}\right]^{2-}$ in the oxidation of TA by potassium bromate catalyzed with $\mathrm{Ru}$ (III) in acidic medium. Therefore, all the experiments were carried out in the presence of mercuric acetate.

Another important point is to establish the reactive species that participated in any given reaction. Potassium bromate has been used as an oxidant for a variety of compounds in acidic medium. It is reported [33] that potassium bromate exists in the presence of acid in the following equilibria:

$$
\begin{aligned}
& \mathrm{BrO}_{3}^{-}+\mathrm{H}^{+} \rightleftharpoons \mathrm{OBrO}_{2} \mathrm{H} \\
& \mathrm{OBrO}_{2} \mathrm{H}+\mathrm{H}^{+} \rightleftharpoons\left(\mathrm{OBrO}_{2} \mathrm{H}\right)^{+}
\end{aligned}
$$

In acid solutions, $\mathrm{Br}(\mathrm{V})$ exists in unprotonated $\left(\mathrm{BrO}_{3}{ }^{-}\right)$ and protonated $\left(\mathrm{OBrO}_{2} \mathrm{H}\right.$ and $\left.\mathrm{OBr}^{+} \mathrm{O}_{2} \mathrm{H}_{2} / \mathrm{Br}^{+} \mathrm{O}_{2}\right)$ forms. Amis et al. [34] proposed $\mathrm{Br}^{+} \mathrm{O}_{2}$ as the oxidizing species in acid bromate oxidation of iodide. Beck and co-workers [35] suggested that both $\mathrm{OBrO}_{2} \mathrm{H}$ and $\mathrm{OBr}^{+} \mathrm{O}_{2} \mathrm{H}_{2}$ are the existing form of bromate in moderately strong acid medium. Sanjeeva Reddy and Sundaram [36] also been verified these results. From the above equilibria (a) and (b), it is evident that with positive effect of $\left[\mathrm{H}^{+}\right]$on the reaction velocity (either first order or second order with respect to $\left[\mathrm{H}^{+}\right]$), $\mathrm{OBrO}_{2} \mathrm{H}$ or $\mathrm{OBr}^{+} \mathrm{O}_{2} \mathrm{H}_{2}$ can be taken as the reactive species of potassium bromate in the reaction mixture. Further, if under the experimental conditions, the equilibrium (c) is assumed to be in existence, then with zero effect of $\left[\mathrm{H}^{+}\right]$on the rate of reaction only the species $\mathrm{Br}^{+} \mathrm{O}_{2}$ can be taken as the reactive species of bromate in the reaction. Under our experimental conditions, the positive effect of $\left[\mathrm{H}^{+}\right]$on the rate of reaction, $\mathrm{OBrO}_{2} \mathrm{H}$ can safely be assumed as the reactive species of bromate in acidic medium on the Ru (III) catalyzed oxidation of TA. The negligible effect of ionic strength also supports the existence of $\mathrm{HBrO}_{3}$ as the reactive species of bromate and excludes the involvement of other species. The results indicate that reactive species of bromate i.e. $\mathrm{HBrO}_{3}$ reacts with the reactive species of catalyst i.e. $\mathrm{Ru}(\mathrm{III})$ in a slow step to give $\mathrm{Ru}(\mathrm{V})$ and $\mathrm{Br}(\mathrm{III})$. This further followed by other fast steps to give products. The formation of $\mathrm{Ru}(\mathrm{V})$ is in accord with earlier reported works [37]. However, in view of the very low concentration of $\mathrm{Ru}(\mathrm{III})$ used, no kinetic evidence could be obtained for the formation of $\mathrm{Ru}(\mathrm{V})$.

In view of above observations, a general mechanism is proposed in Scheme 1 for the Ru (III) catalyzed oxidation of TA by potassium bromate in $\mathrm{HClO}_{4}$ medium to account for the experimental observations:

According to Scheme 1 and considering the fact that one mol of TA is oxidized by one mole of $\mathrm{KBrO}_{3}$, the rate of reaction in terms of decrease in the concentration of $\mathrm{KBrO}_{3}$ can be expressed as:

$-\frac{\mathrm{d}[\mathrm{KBrO} 3]}{\mathrm{dt}}=\mathrm{k}[\mathrm{Ru}(\mathrm{III})]\left[\mathrm{HBrO}_{3}\right]$

From Scheme 1 rate law (2) is obtained.

Rate $=\frac{\mathrm{kk}_{1} \mathrm{~K}_{2}\left[\mathrm{H}^{+}\right]\left[\mathrm{BrO}_{3}^{-}\right]\left[\mathrm{Cl}^{-}\right][\mathrm{Ru}(\mathrm{III})]_{\mathrm{T}}}{\mathrm{k}_{-1}+\mathrm{k}_{1}\left[\mathrm{Cl}^{-}\right]+\mathrm{kK}_{2}\left[\mathrm{H}^{+}\right]\left[\mathrm{BrO}_{3}^{-}\right]}$
Equation (2) is the rate law on the basis of which observed kinetic orders with respect to each reactant of the reaction can very easily be explained.

On reversing the equation (2), we have equation (3)

$\frac{[\mathrm{Ru}(\mathrm{III})]_{\mathrm{T}}}{\text { Rate }}=\frac{1}{\mathrm{kK}_{1} \mathrm{~K}_{2}\left[\mathrm{BrO}_{3}^{-}\right]\left[\mathrm{H}^{+}\right]\left[\mathrm{Cl}^{-}\right]}+\frac{1}{\mathrm{kK}_{2}\left[\mathrm{BrO}_{3}^{-}\right]\left[\mathrm{H}^{+}\right]}+\frac{1}{\mathrm{k}_{1}\left[\mathrm{Cl}^{-}\right]}$

Equation (3) indicates that if a plot is made between $[\mathrm{Ru}$ (III) $]_{\mathrm{T}} /$ Rate and $1 /\left[\mathrm{BrO}_{3}{ }^{-}\right]$or $1 /\left[\mathrm{H}^{+}\right]$or $1 /\left[\mathrm{Cl}^{-}\right]$, a straight line with positive intercept on $\mathrm{y}$-axis will be obtained. Straight line with positive intercepts on $y$ - axis obtained by the plots of $1 /$ Rate versus $1 /\left[\mathrm{BrO}_{3}{ }^{-}\right]$(Fig. 5), $1 /\left[\mathrm{H}^{+}\right]$(Fig. 6) and $1 /\left[\mathrm{Cl}^{-}\right]$ (Fig. 7) proves the validity of the rate law (2) the proposed reaction scheme, on the basis of which the rate law (2) has been derived. From the values of the intercepts and slopes of the plots, the values of $\mathrm{k}_{1}, \mathrm{~K}_{1}$ and $\mathrm{kK}_{1} \mathrm{~K}_{2}$ have been calculated and are found to be $7.69 \mathrm{sec}^{-1}, 2.5 \times 10^{2} \mathrm{~mol}^{-1}$ lit and $2.27 \mathrm{x}$ $10^{3} \mathrm{~mol}^{-1}$ lit respectively for the oxidation of tartaric acid.

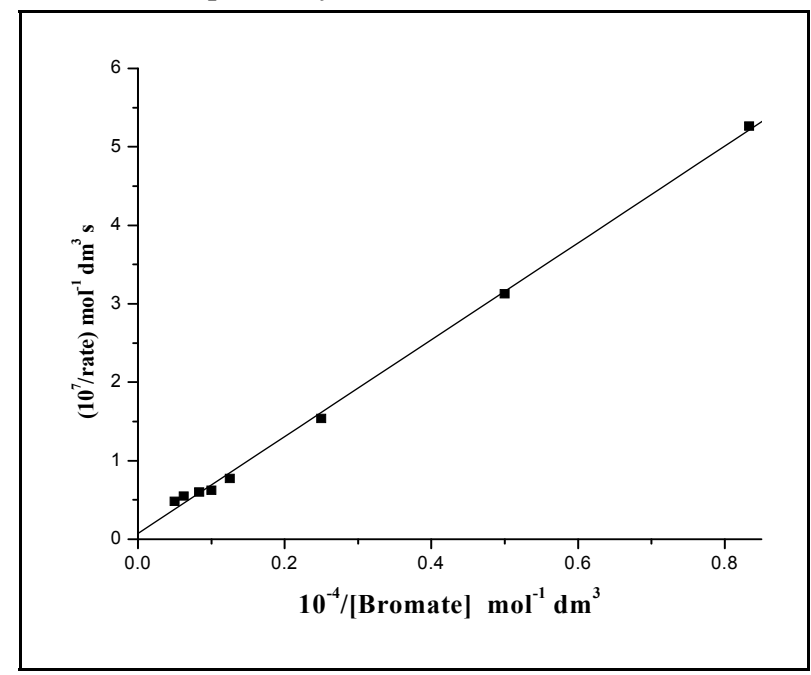

Fig. (5). Plot between $1 /$ rate and $1 /$ bromate $]$ at $35^{\circ} \mathrm{C},[\mathrm{TA}]=1.0 \times 10^{-}$ $\mathrm{mol} \mathrm{dm}{ }^{-3},[\mathrm{Ru}(\mathrm{III})]=9.15 \times 10-5 \mathrm{~mol} \mathrm{dm}^{-3},[\mathrm{HClO} 4]=0.8 \times 10^{-1} \mathrm{~mol}$ $\mathrm{dm}^{-3},\left[\mathrm{Hg}(\mathrm{OAc})_{2}\right]=4.00 \times 10^{-3} \mathrm{~mol} \mathrm{dm}^{-3},[\mathrm{KCl}]=10^{-3} \mathrm{~mol} \mathrm{dm}^{-3}$.

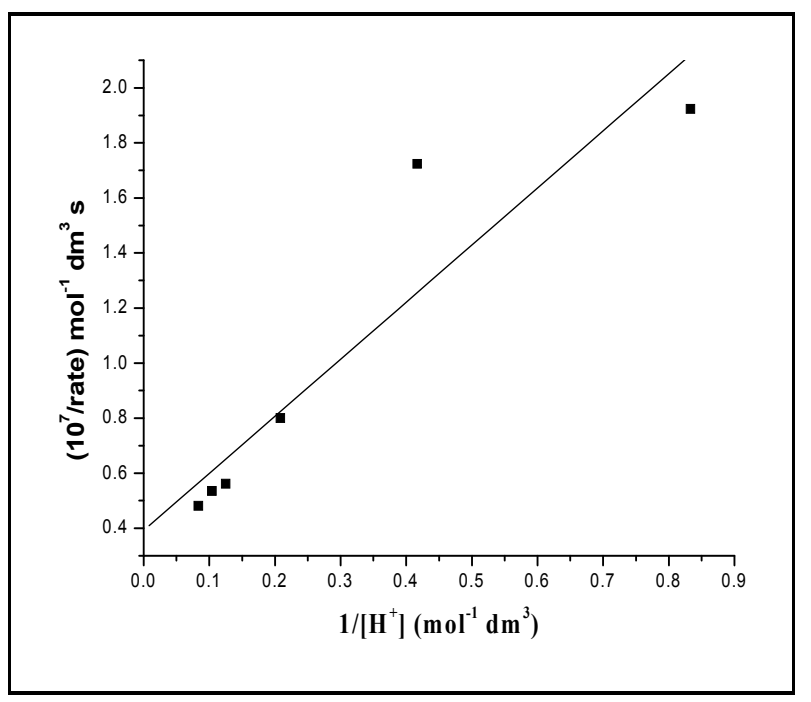

Fig. (6). Plot between $1 /$ rate and $1 /\left[\mathrm{H}^{+}\right]$at $35^{\circ} \mathrm{C},\left[\mathrm{KBrO}_{3}\right]=10 \times 10^{-4}$ $\mathrm{mol} \mathrm{dm}{ }^{-3},[\mathrm{TA}]=2.0 \times 10^{-1} \mathrm{~mol} \mathrm{dm}^{-3}$, $[\mathrm{Ru}(\mathrm{III})]=9.15 \times 10^{-5} \mathrm{~mol} \mathrm{dm}^{-3}$, $\left[\mathrm{Hg}(\mathrm{OAc})^{2}\right]=1.60 \times 10^{-3} \mathrm{~mol} \mathrm{dm}^{-3},[\mathrm{KCl}]=10^{-3} \mathrm{~mol} \mathrm{dm}^{-3}$. 


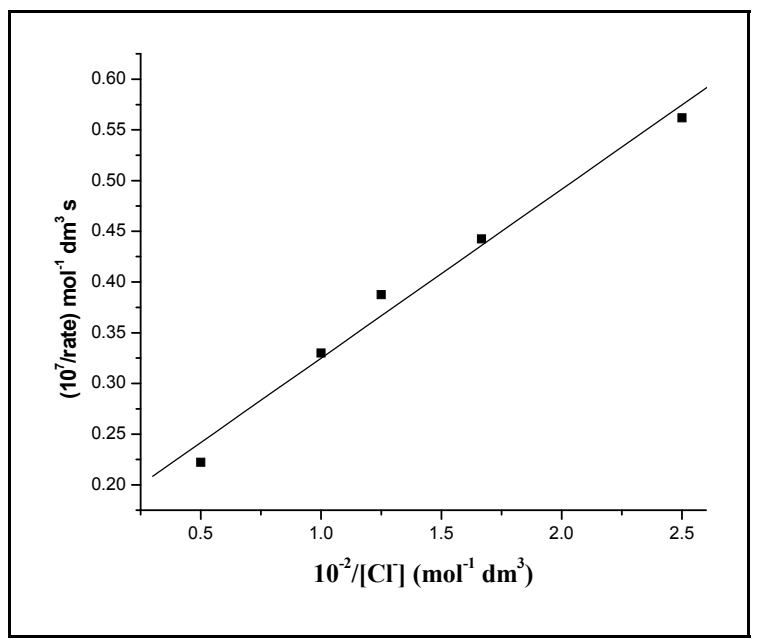

Fig. (7). Plot between $1 /$ rate and $1 /[\mathrm{Cl}-]$ at $35^{\circ} \mathrm{C},\left[\mathrm{KBrO}_{3}\right]=10 \times 10^{-4}$ mol dm${ }^{-3},[\mathrm{TA}]=2.0 \times 10^{-1} \mathrm{~mol} \mathrm{dm}{ }^{-3},[\mathrm{Ru}(\mathrm{III})]=9.15 \times 10^{-5} \mathrm{~mol} \mathrm{dm}{ }^{-3}$, $\left[\mathrm{Hg}(\mathrm{OAc})^{2}\right]=1.60 \times 10^{-3} \mathrm{~mol} \mathrm{dm}^{-3},\left[\mathrm{H}^{+}\right]=0.8 \times 10^{-1} \mathrm{~mol} \mathrm{dm}^{-3}$.

\subsection{Effect of Dielectric Constant and Ionic Strength of the Medium}

In order to determine the effect of the dielectric constant (D) of the medium on the reaction rate, the reaction was studied with different dielectric constants for the medium at constant concentration of all other reactants and at a constant temperature of $35^{\circ} \mathrm{C}$. The change in dielectric constant of the medium was done by the addition of acetic acid to the reaction mixture. Before conducting experiments for the study of the effect of dielectric constant of the medium on reaction rate, we performed experiments taking acetic acid as an organic substrate instead of TA in usual manner and were found that acetic acid was not oxidized by bromate in the presence of $\mathrm{Ru}$ (III) as the homogeneous catalyst. Addition of acetic acid to the reaction mixture increased the reaction rate. The plot of $\log \mathrm{k}^{1}$ versus $1 / \mathrm{D}$ was linear with positive slopes. The dependence of the rate constant on the dielectric constant of the medium is given by the following equation:

$$
\begin{aligned}
& {\left[\mathrm{RuCl}_{2}\left(\mathrm{H}_{2} \mathrm{O}\right)_{3} \mathrm{OH}\right]+\mathrm{Cl}^{-}} \\
& \mathrm{BrO}_{3}^{-}+\mathrm{H}^{+} \\
& \mathrm{Ru}(\mathrm{III})+\mathrm{Br}(\mathrm{V})
\end{aligned}
$$

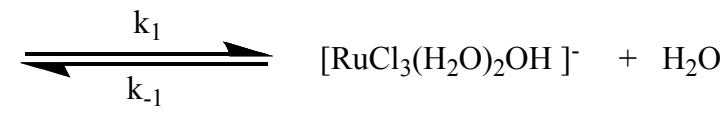

$\mathrm{Ru}(\mathrm{III})$

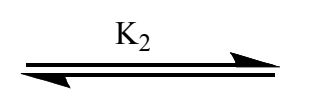

$$
\mathrm{HBrO}_{3}
$$$$
\operatorname{Br}(\mathrm{V})
$$

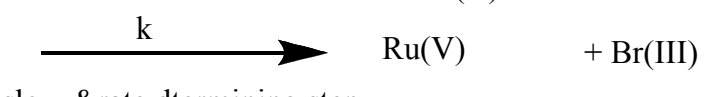

slow \&rate dtermining step

$\left(\mathrm{BrO}_{2}^{-}\right)$

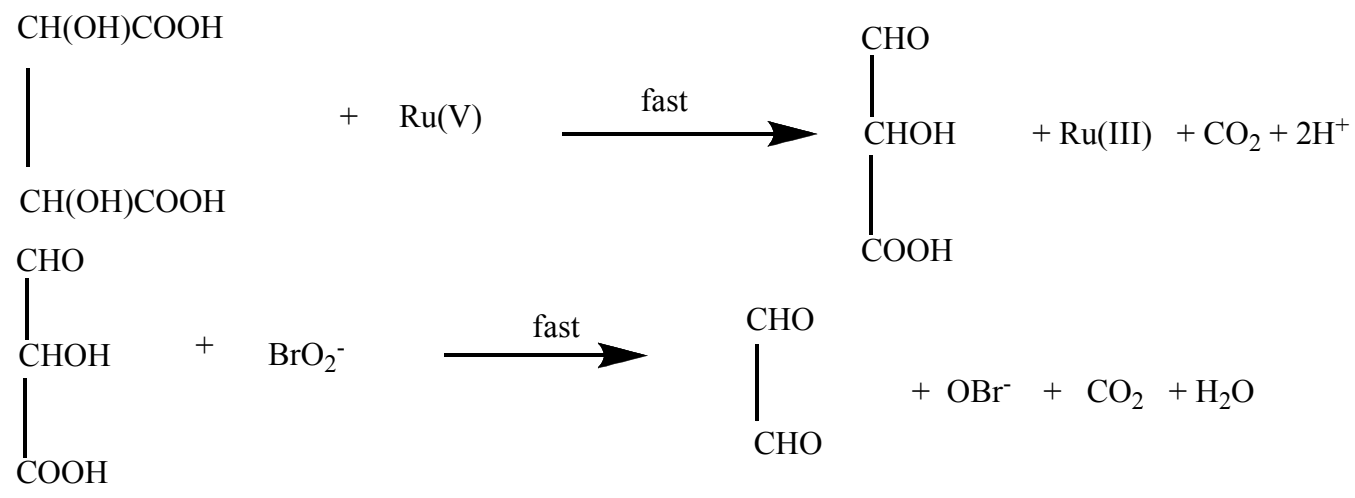

$\mathrm{COOH}$

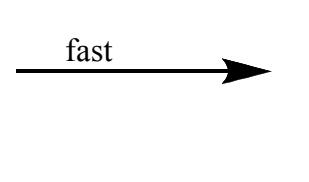

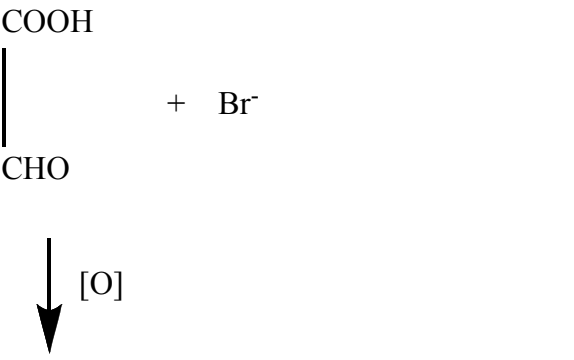

Scheme 1.

$\mathrm{HCOOH}+\mathrm{CO}_{2}$ 
$\ln \mathrm{k}^{1}=\ln \mathrm{k}_{0}^{1}-\left(\frac{\mathrm{NZ}_{\mathrm{A}} \mathrm{Z}_{\mathrm{B}} \mathrm{e}^{2}}{\mathrm{DRTr}_{\#}}\right)$

In this equation, $\mathrm{k}^{1}$ is the rate constant in a medium of infinite dielectric constant, $\mathrm{Z}_{\mathrm{A}} \mathrm{e}$ and $\mathrm{Z}_{\mathrm{B}} \mathrm{e}$ are the total charges on the ions $\mathrm{A}$ and $\mathrm{B}, \mathrm{r}_{\#}$ the radius of the activated complex, $\mathrm{R}, \mathrm{T}$ and $\mathrm{N}$ have usual meanings. This equation predicts a linear plot of $\log \mathrm{k}^{1}$ against $1 / \mathrm{D}$ with a negative slope if the charges on the ions are of the same sign and a positive slope is they are of opposite sign (CHECK THIS LINE). The positive dielectric effect observed in the present studies (Table 3) clearly support step (iii) of the proposed mechanism (reaction Scheme 1), The ionic strength (I) effect on the rate of reaction can be described according to the theory of Bronsted and Bjerrum which postulated the reaction through the formation of an activated complex. According to this theory, the effect of ionic strength on the rate of reaction involving two ions can be given by the relationship:

$\log \mathrm{k}=\log \mathrm{k}_{\mathrm{o}}+1.02 \mathrm{Z}_{\mathrm{A}} \mathrm{Z}_{\mathrm{B}} \mathrm{I}^{1 / 2}$

Here $Z_{A}$ and $Z_{B}$ are the valencies of the ions $A$ and $B, k$ and $\mathrm{k}_{\mathrm{o}}$ are the rate constants in the presence and absence of the added electrolyte, respectively. A plot of $\log \mathrm{k}$ against $\mathrm{I}^{1 / 2}$ should be linear with a slope of $1.02 \mathrm{Z}_{\mathrm{A}} \mathrm{Z}_{\mathrm{B}}$. If $\mathrm{Z}_{\mathrm{A}}$ and $\mathrm{Z}_{\mathrm{B}}$ have similar signs, the quantity $Z_{A} Z_{B}$ is positive and rate increases with the ionic strength exhibiting a positive slope, while if the ions have dissimilar charges, the quantity $Z_{A} Z_{B}$ is negative and the rate of reaction decreases with the increase in ionic strength and exhibiting negative slope. In the present case, the negligible effect of ionic strength on the reaction rate indicate the involvement of a neutral molecule $[38,39]$ as one of the species in the rate determining step, as given in Scheme 1.

An effort has also been made to compare our experimental findings with the earlier reported results for oxidation of TA by bromate in acidic medium. In the present study, behavior of oxidant is first order kinetics at low concentration tending to zero order at high concentration. In the earlier reported uncatalysed work, results show first order dependence in TA, but in the present investigation zero order dependence of TA by same oxidant. Ru (III) catalyzed oxidation of TA is faster than uncatalysed reaction. Recently we also reported the kinetic and mechanistic study on the oxidation of hydroxy acid by N-bromophthalimide (NBP) in the presence of a micellar system [1]. In the present study, behavior of substrate is somewhat different from that of NBP.

\section{CONCLUSION}

The $\mathrm{Ru}$ (III) catalyzed oxidation of tartaric acid by potassium bromate was studied at $35^{\circ} \mathrm{C}$. Oxidation of tartaric acid by potassium bromate in perchloric acid medium becomes facile in the presence of micro- quantity of Ru (III) catalyst. Oxidation products have been identified. Among the various species of $\mathrm{Ru}$ (III) in acidic medium, $\left[\mathrm{RuCl}_{2}\left(\mathrm{H}_{2} \mathrm{O}\right)_{3} \mathrm{OH}\right]$ was the reactive species, where as $\mathrm{OBrO}_{2} \mathrm{H}$ was considered to be the reactive species of the oxidant i.e. bromate. Activation parameters were evaluated for the catalyzed reaction. A plausible mechanism and a related rate law have been worked out. It can be concluded that $\mathrm{Ru}$ (III) is an efficient catalyst in the oxidation of the tartaric acid by potassium bromate in acid medium.

\section{CONFLICT OF INTEREST}

The authors confirm that this article content has no conflict of interest.

\section{ACKNOWLEDGEMENTS}

One of us (Ajaya Kumar Singh) is thankful to UGC, Regional office, Bhopal, MP, India for award of Teacher Research Fellowship.

\section{REFERENCES}

[1] Patil, S.; Katre, Y.R.; Singh, A.K. A kinetic and mechanistic study on the oxidation of hydroxy acids by N-bromophthalimide in presence of micellar system. J. Surfactants Deterg., 2007, 10, 175184.

[2] Singh, A.K.; Jain, B.; Negi, R.; Katre, Y.R.; Singh, S.P. Oxidation of valine by $\mathrm{N}$ - bromophthalimide in presence of chloro-complex of $\mathrm{Pd}(\mathrm{II})$ as homogenouscatalyst: A kinetic and mechanistic study. Open Catal. J., 2009, 2, 12-20.

[3] Singh, A.K.; Sachdev, N.; Srivastava, A.; Katre, Y.R.; Singh, S.P. A novel and facile oxidation of D-Glucose by N-bromophthalimide in the presence of chloro -complex of ruthenium (III). Synth. Reactivity Inorg. Metal Org. Nano Metal Chem., 2010, 40, 947954.

[4] Singh, A.K.; Jain, B.; Negi, R.; Katre, Y.R.; Singh, S.P.; Sharma, V.K. Kinetic study Ru(III)-catalyzed oxidation of glycine by Nbromophthalimide in acidic medium. Transit Metal Chem., 2010, $35,407-414$.

[5] Singh, A.K.; Jain, B.; Negi, R.; Katre, Y.R.; Singh, S.P.; Sharma, V.K. Kinetic study of oxidation of valine by N-bromophthalimide in presence of iridium (III) chloride as homogenous catalyst. Synth. Reactivity Inorg. Metal Org. Nano Metal Chem., 2010, 40, 71-77.

[6] Singh, A.K.; Jain, B.; Negi, R.; Katre, Y.R.; Singh, S.P.; Sharma V.K. Kinetics and mechanism of oxidation of $\beta$-Alanine by Nbromophthalimide in presence of $\mathrm{Ru}(\mathrm{III})$ chloride as homogenous catalyst in acidic medium. Transit Metal Chem., 2009, 34, 521-528.

[7] Singh, A.K.; Jain, B.; Negi, R.; Katre, Y.R.; Singh, S.P.; Sharma, V.K. A novel oxidation of valine by N-bromophthalimide in the presence of Ruthenium(III) chloride as a homogeneous catalyst. Catal. Lett., 2009, 131, 98-104.

[8] Madhu, S.; Gupta, R.; Singh, A.; Singh, B.; Singh, A.K. Kinetics and mechanism of oxidation of some hydroxy acids by $N$ bromoacetamide. J. Mol. Catal, 1991, 65, 317-327.

[9] Mentasti, E.; Kirschenbaum, L.J. Oxidation of organic compounds by silver(II). Reactions with aliphatic diols and $\alpha$-hydroxy acids. Inorg. Chim. Acta, 1987, 134, 283-288.

[10] Saxena, R.; Upadhyay, S.K. Kinetics and mechanism of the ruthenium(III)-catalyzed oxidation of hydroxy-acids by $N$ bromosuccinimide. Transit. Metal Chem., 1991, 16, 245-248.

[11] Din, Kabir-ud; Hartani, K.; Khan, Z. One-step three electron oxidation of tartaric and lyoxylic acids by chromium (VI) in the absence and presence of manganese(II). Transit. Metal Chem., 2002, 27, 617-624.

[12] Kumar, P.; Gupta, K.C.; Vehari, K. Ruthenium(VI) catalyzed oxidation of sodium salts of lactic, tartaric and glycolic acid by alkaline hexacyanoferrate(III). React. Kinet. Catal. Lett., 1985, 29, 297-305.

[13] Singh, S.P.; Singh, A.K.; Singh, A.K. Mechanistic study of Ir (III)catalyzed oxidation of D-glucose by potassium iodate in aqueous alkaline medium. J. Carbohydr. Chem., 2009, 28, 278-292.

[14] Singh, A.K.; Negi, R.; Jain, B.; Katre, Y.R.; Singh, S.P.; Sharma, V.K Kinetics a mechanism of Ru(III) catalyzed oxidation of paracetamol by chloramine- $\mathrm{T}$ in aqueous acidic medium. Catal. Lett., 2009, 132, 285.

[15] Singh, A.K.; Negi, R.; Katre, Y.R.; Singh, S.P. Mechanistic study of novel oxidation of paracetamol by chloramine-T using microamount of chloro-complex of Ir (III) as a homogeneous catalyst in acidic medium. J.Mol. Catal. A Chem., 2009, 302, 36-42.

[16] Singh, A.K.; Negi, R.; Jain, B.; Katre, Y.R.; Singh, S.P.; Sharma, V.K. Pd(II) catalyzed oxidative degradation of paracetamol by 
chloramine-T in acidic and alkaline media. Ind. Eng. Chem. Res., 2011, 50, 8407-8419

[17] Singh, A.K.; Singh, A.K.; Singh, V.; Rahmani, S.; Ashish,; Singh, B. Ruthenium(III) catalyzed oxidation of diethanolamine and triethanolamine by $\mathrm{Br}(\mathrm{V})$ in presence of perchloric acid: A kinetic and mechanistic study. J. Chem.Res., 2006, 8, 56-63.

[18] Ashish,; Singh, S.P.; Singh, A.K.; Singh, B. Mechanistic study of osmium(VIII)promoted oxidation of crotonic acid by aqueous alkaline solution of potassium bromate. Transit. Metal Chem., 2005, 30, 610- 615 .

[19] Singh, B.; Srivastava, S. Kinetics and mechanism of ruthenium tetroxide catalysed oxidation of cyclic alcohols by bromate in a base. Transit. Metal Chem., 1991, 16, 466-468.

[20] Desai, S.M.; Halligudi, N.N.; Nandibewoor, S.T. Kinetics of osmium(VIII) catalyzed oxidation of allyl alcohol by potassium bromate in aqueous acidic medium-autocatalysis in catalysis. Int. $J$. Chem. Kinet., 1999, 31, 583-589.

[21] Desai, S.M.; Halligudi, N.N.; Nandibewoor, S.T. Kinetics and mechanism of ruthenium(III)-catalysed oxidation of allyl alcohol by acid bromate-autocatalysis in catalysis. Transit. Metal Chem., 2002, 27, 207-212.

[22] Bailar, J.C. The Chemistry of Coordination Compounds. Reinhold: New York, 1956, p. 4.

[23] Sengupta, K.K.; Banerjee, A.; Chatterjee, H. Oxidative behaviours and relative reactivities of some $\alpha$-hydroxy acids towards bromate ion in hydrochloric acid medium. Tetrahedron, 1992, 48, 53235330 .

[24] Feigl, F. Spot Tests in Organic Analysis. $7^{\text {th }}$ ed; Elsevier: Amsterdam, 1966, pp. 451-452.

[25] Cady, H.H.; Connick, R.E. The determination of the formulas of aqueous ruthenium(III) species by means of ion-exchange resin: $\mathrm{Ru}^{+3}, \mathrm{RuCl}^{+2}$ and $\mathrm{RuCl}_{2}^{+}$. J. Am. Chem. Soc., 1958, 80, 2646-2652.

[26] Connick, R.E.; Fine, D.A. Ruthenium(III) chloride complexes: $\mathrm{RuCl}_{2}{ }^{+}$, J. Am. Chem. Soc., 1960, 82, 4187-4191.

[27] Davfokratova, T. Analytical Chemistry of Ruthenium, Israel Program of Scientific Translations. Academy of Sciences: USSR, 1963, pp. 54, 71, and 97.
[28] Griffith, W.P. The Chemistry of Rare Platinum Metals. WileyInterscience: New York, 1967, p. 141.

[29] Singh, A.K.; Singh, V.; Singh, A.K.; Gupta N.; Singh, B. Kinetics and mechanism of $\mathrm{Ru}(\mathrm{III})$ and $\mathrm{Hg}(\mathrm{II})$ catalyzed oxidation of $\mathrm{D}$ galactose and D-ribose by N-bromoacetamide in perchloric Acid. Carbohydr. Res., 2002, 337, 345-351.

[30] Singh, M.P.; Singh, H.S.; Verma, M.K. Kinetics and mechanism of the ruthenium(III) chloride catalyzed oxidation of butanone-2 and pentanone- 3 by cerium(IV) sulfate in aqueous sulfuric acid medium. J. Phys. Chem., 1980, 84, 256-259.

[31] Taqui Khan, M.M.; Ramachandraiah, G.; Rao, A.P. Ruthenium(III) chloride in aqueous solution: electrochemical and spectral studies. Inorg.Chem., 1986, 25, 665-670.

[32] Singh, A.K.; Rahmani, S.; Singh, B.; Singh, R.K.; Singh, M. Mechanism of $\mathrm{Ir}(\mathrm{III})$ - catalysed and $\mathrm{Hg}(\mathrm{II})$-co-catalysed oxidation of reducing sugars by $\mathrm{N}$-bromoacetamide in acidic medium. $J$. Phys. Org. Chem., 2004, 17, 249-256.

[33] Edward, J.O. Rate laws and mechanisms of oxyanion reactions with bases. Chem. Rev., 1952, 50, 455-482.

[34] Amis, E.S.; Indelli, A.; Nolen, G. Salt effects in the reaction between bromate and iodide ions. J. Am. Chem. Soc., 1960, 82, 3233-3236.

[35] Beck, M.T.; Rabai, G.; Bazsa, G. Kinetic investigation of the bromate-ascorbic acid-malonic acid system. Int. J. Chem. Kinet., 1981, 13, 1277-1288.

[36] Reddy, C.S.; Sundaram, E.V. Mechanism of acid bromate oxidation of trans mono-substituted cinnamic acids: structure reactivity correlation - a non-linear hammett's plot. Tetrahedron, 1989, 45, 2109-2126.

[37] Simoyi, R.H.; Epstein, I.R.; Kustin, K. Kinetics and mechanism of the oxidation of thiourea by bromate in acidic solution. J. Phys. Chem., 1994, 98, 551-557.

[38] Frost, A.; Pearson, R.G. Kinetics and Mechanism, $2^{\text {nd }}$ ed; John Wiley and Sons Inc.: New York, 1953, pp. 145-147.

[39] Laidler, K.J. Chemical Kinetics, $3^{\text {rd }}$ ed; Pearson Education Company: India, 2004, p. 198.

This is an open access article licensed under the terms of the Creative Commons Attribution Non-Commercial License (http://creativecommons.org/licenses/by-nc/ $3.0 /$ ) which permits unrestricted, non-commercial use, distribution and reproduction in any medium, provided the work is properly cited. 